\title{
Endophytic mycobiota recorded from Clerodendrum inerme and their biological activities
}

\author{
Madhankumar Dhakshinamoorthyand Kannan Kilavan Packiam \\ Department of Biotechnology, Bannari Amman Institute of Technology, Sathyamangalam, Erode District-638401, TamilNadu, India. \\ Corresponding authors Email:drkpkannan@gmail.com \\ (Submitted on July 15, 2019; Accepted on November 30, 2019)
}

\section{ABSTRACT}

Endophytic fungi were isolated from the medicinal plant, Clerodendrum inerme (L.) Gaertn., which was collected from Western Ghats of Sathyamangalam Tiger Reserve, Sathyamangalam, Erode District, Tamil Nadu. As many as 150 segments were screened from leaves, twigs and shoots of selected medicinal plant. A total of 31 species which belong to 31 genera were recorded among which 12 isolates were classified into sterile morpho species. Biodiversity indices such as Gleason index (G) and Shannon index of leaf, shoot, twigs shows the maximum species diversity. Jaccard's similarity coefficient represents the maximum similarity in leaves-twigs (0.20) followed by leaves-shoot (0.2631) and twigsleaves (0.1764). The selected endophytic fungal strains were mass cultured in modified PDB medium at $27 \pm 2^{\circ} \mathrm{C}$ for 14 days. $\mathrm{Mycelia}$ and broth were separated by filtration. The mycelial cells were ultra sonicated and the biological compounds were extracted through chloroform and methanol. The compounds were tested and also quantified, the antioxidant property was evaluated by employing DPPH, FRAP, FTC, TPC, and TBA assays. The antioxidant and free radical scavenging activity recorded was around $99 \%$ inhibition at the concentration of $6.25-20 \mathrm{mg} / \mathrm{mL}$. The total phenolic content of 3.142-4.445 $\pm 2.85 \mu \mathrm{g} / \mathrm{mL}$ was evaluated and compared with standard Tannic acid. The endophytic fungal extract was evaluated for its antibacterial activities. Agar well diffusion exhibits the inhibition range of 15-22mm. The Minimum Inhibitory Concentration showed the antibacterial potency at lower concentration of $12.5-25 \mu \mathrm{g} / \mathrm{mL}$ with all gram positive and gram negative bacterial strains studied.

KEYWORDS: Endophytes, Biodiversity indices, Minimum inhibitory concentration, DPPH, TPC.

\section{INTRODUCTION}

Endophytes are microorganisms that are bacteria or fungi living in plant tissues without causing negative effects to host and capable of producing the natural products useful in medicine and agriculture based industry (Kumar and Sagar, 2007; Bacon and White, 2000; Strobel and Daisy, 2009). Certain tropical forest regions of Guyana and Mudumalai revealed the hyper diverse nature of fungal endophytes. (Cannon and Simmons, 2002; Suryanarayanan et al., 2002) .Endophytes of Curvularia sp. Isolated from petiole, bark and leaf of Alstonia scholaris L. showed antibacterial activity (Mahapatra and Banerjee, 2010). Endophytes are known to produce rich source of natural products to overcome the pathogenic invasion (Tan and Zou, 2001).

It is a common belief that the photochemical and bioactive products produced by endophytes are indicative of the host specificity relationship (Wani et al.,1971). These are reported to have a role in the production of volatile compounds (Bicas et al., 2009; Krings et al., 2006). Metabolites having antibacterial activity are reported to be useful in pharmaceutical industries (Guo et al., 2008). The antimicrobial agents are not only documented to be useful as antibiotics but also in food industry for preservation (Liu et al., 2008). Coumarin, an important bioactive compound was isolated from endophytic fungus Pestalotiopsis versicolor (Speg.) Steyaert, along with other known compounds (Yang et al., 2015). Mucor irregularis Stichigel, Guarro \& Ed. Alvarez, known to be associated with the medicinal plant Moringa stenopetal (Baker f.) Cufod. found in Cameroon, is reported to show biological activity (Akone et al., 2016). Endophytes are also reported to be an important source of novel sesquiterpenes and some of the already known terpenes (Liu et al., 2015).

Natural antioxidants are reported to be of common occurrence in the medicinal plants, vegetables and fruits (Liu et al., 2007; Yu et al., 2010; Huang et al., 2017). Endophytic microorganisms are known to produce polysaccharides with antioxidant properties (Liu et al., 2009). Some of the well known endophytes are reported to produce volatile organic compounds such as cycloalkenes, cycloalkanes and benzene derivatives (Mallette, et al., 2014). The primary objective of the present study is to isolate and identify the endophytic fungi from Clerodendrum inerme (L.) Geartn., and to study their antimicrobial and antioxidant activity.

\section{MATERIALSAND METHODS}

Plant sample collection: The medicinal plant of Clerodendrum inerme belongs to family Lamiaceae. It is commonly known as 'Sanganguppi' in Tamil dilect. The plant sample was taken from Thalamalai range of Sathyamangalam Tiger Reserve (STR) and kept in paper bags and processed within 24 hours following collection (Petrini, 1986).

Isolation and Identification of endophytic fungi: The endophytic fungi were isolated from Clerodendrum inerme through modified surface sterilization technique. These were subsequently identified based on morphological and microscopic features consulting authentic literature (Guba 1961; Ellis 1971; Sutton 1980 and Nag Raj 1993). The identified endophytes were cry preserved at Endophytic Fungal Culture Collection Centre (EFCCC), Department of Biotechnology, BIT, and Sathyamangalam.

Statistical Analysis: Relative Percentage Occurrence, Colonization Frequency, Jaccard's Similarity Co-efficient and species diversity (Shannon Diversity index and Gleason index) were calculated for the endophytic assemblage (Suryanarayanan etal., 2002; Kannan, 2017).

Selection of medium and endophytic fungal positive strain: The shake flask experiment was carried out for preliminary screening of secondary metabolites. The pre-dominant entophytic fungi were cultured in $100 \mathrm{~mL}$ of modified Potato Dextrose Broth for undertaking studies pertaining to antioxidant activities. For the screening of antimicrobial compounds culturing was done in $250 \mathrm{~mL}$ Erlenmeyer flasks followed by 
incubation at $27 \pm 2^{\circ} \mathrm{C}$ for 14 days.

Extraction of cell-free extract for screening of secondary metabolites: Mycelia and broth were centrifuged at 10,000 rpm for 10 minutes at $4^{\circ} \mathrm{C}$. The pellet was transferred into a sterile container and dried overnight in a hot air oven at $40^{\circ} \mathrm{C}$. The dried mycelia and methanol was pulverized with the help of ultra sonicator at $100 \%$ frequency and the extraction was repeated with chloroform and methanol mixed in the ratio of $4: 1$. The crude fungal compounds were extracted and further subjected to preliminary screening for secondary metabolite. The crude was stored at $4^{\circ} \mathrm{C}$ for further studies (Mussagy et al., 2019; Zhangetal., 2018).

Procurement of Test Bacteria: Six bacterial strains, namely Bacillus subtilis (MTCC 121), Escherichia coli (MTCC 433), Staphylococcus aureus (MTCC -3160), Klebsiella plenticola (MTCC - 530), Proteus vulgaris (MTCC 426), and Lactobacillus lactis (MTCC 4185) were procured from Microbial Type Culture Collection (MTCC), Gene Bank, Chandigarh, India. The stock cultures were maintained on slants of Nutrient agar at $4^{\circ} \mathrm{C}$. Active cultures for screening their susceptibility were prepared by transferring loop full of cultures from stock cultures to test tubes containing nutrient broth which were incubated at $37^{\circ} \mathrm{C}$ for 24 hours using Micro broth dilution method. The fungal extracts were screened against 4 bacterial strains. (Tamilarasan et al., 2013).

Determination of Minimum Inhibitory Concentration (MIC): The fungal extract $(100 \mu \mathrm{g} / \mathrm{mL})$ as an initial concentration was taken in the first well of 96 well titre plate. This was serially diluted resulting in $50 \mu \mathrm{g} / \mathrm{mL}, 25 \mu \mathrm{g} / \mathrm{mL}$, $12.5 \mu \mathrm{g} / \mathrm{mL}, 6.25 \mu \mathrm{g} / \mathrm{mL}, 3.125 \mu \mathrm{g} / \mathrm{mL}, 1.6 \mu \mathrm{g} / \mathrm{mL}$ and finally $0.8 \mu \mathrm{g} / \mathrm{mL}$ of extract in series. Each well with respective concentration of fungal extract was inoculated with $0.01 \mathrm{~mL}$ of 24 hours bacterial cell suspension. Streptomycin was used as a positive control and methanol was used as a negative control. This was incubated at $37^{\circ} \mathrm{C}$ for 24 hours. The presence of turbidity of the broth indicates positive growth (Udayaprakash etal., 2013).

DPPH Radical Scavenging Assay: Different reactions of methanolic extracts of fungal sources $(10-50 \mathrm{mg} / \mathrm{mL})$ were taken and the total volume was made up to $250 \mu \mathrm{L}$ with chloroform and methanol, respectively. $1 \mathrm{~mL}$ of DPPH (4 mg/ $100 \mathrm{~mL}$ ) was added and the tubes were kept in dark for incubation at room temperature for $20 \mathrm{~min}$. The absorbance was checked against the blank at $517 \mathrm{~nm}$. Per cent free radical scavenging was calculated based on the extent of reduction in the colour (Udayaprakash et al., 2015).

The per cent radical scavenging activity was calculated by applying the following relation:

$\%$ Radical scavenging $=\{($ Ac As $) / A c\} X 100$

Where $\mathrm{Ac}=$ Absorbance of control and $\mathrm{As}=$ Absorbance of test sample.

Ferric Reducing Antioxidant Power (FRAP) Assay : $1 \mathrm{~mL}$ of fungal extract, $2.5 \mathrm{~mL}$ phosphate buffer (of $0.2 \mathrm{M}, \mathrm{pH} 7$ ) and $1 \%$ potassium ferri cyanide $(2.5 \mathrm{~mL})$ were mixed and incubated at $50^{\circ} \mathrm{C}$ for $30 \mathrm{~min}$. To this solution, $2.5 \mathrm{~mL}$ of $10 \%$ trichloro acetic acid was added and centrifuged at $6500 \mathrm{rpm}$ for $10 \mathrm{~min}$. Distilled water $(2.5 \mathrm{~mL})$ and then $0.5 \mathrm{~mL}$ of $0.1 \%$ Ferric chloride were added to $2.5 \mathrm{~mL}$ of the supernatant. The absorbance of the solution was measured at $700 \mathrm{~nm}$ using UVvisible spectrophotometer. The reducing ability of the fungal extract was evaluated in terms of percentage by relating to the standard, Ferrous sulphate (Udayaprakash, et al., 2015).

Percentage inhibition $=$ Absorbance of the control (Ac) - Absorbance of the sample (As) $) \times 100$

Ferric Thiocyanate (FTC) Assay: FTC assay involves the addition of $120 \mu \mathrm{L}$ of $98 \%$ ethanol, $100 \mu \mathrm{L}$ of $2.51 \%$ linoleic acid in ethanol and $9 \mathrm{~mL}$ of $40 \mathrm{mM}$ phosphate buffer $(\mathrm{pH} 7)$ to $100 \mu \mathrm{L}$ of the fungal extract. To $100 \mu \mathrm{L}$ of the mixture, $9.7 \mathrm{~mL}$ of $75 \%$ ethanol, $100 \mu \mathrm{L}$ of $30 \%$ ammonium thiocyanate and $100 \mu \mathrm{L}$ of $20 \mathrm{mM} \mathrm{FeCl}_{3}$ in $3.5 \% \mathrm{HCl}$ were added after maintaining the solution in the dark, at $40^{\circ} \mathrm{C}$. The absorbance of the solution was measured at $500 \mathrm{~nm}$ using UV-visible spectrophotometer after $3 \mathrm{~min}$. The percentage of inhibition was calculated with Tannic acid as the standard (Udayaprakash et al., 2015).

$\%$ Inhibition $=$ Absorbance of the control $(\mathrm{Ac})-$ Absorbance of the sample (As) $) \times 100$

Thiobarbituric Acid (TBA) Assay: Equal volume $(200 \mu \mathrm{L})$ of $20 \%$ trichloro acetic acid and $0.67 \%$ thio-barbituric acid were mixed with $1 \mathrm{~mL}$ of $2.51 \%$ linoleic acid and $1 \mathrm{~mL}$ of fungal extract. The solution was maintained in boiling water bath for $10 \mathrm{~min}$; cooled to room temperature and centrifuged at $3000 \mathrm{rpm}$. The percentage inhibition of the fungal sources against the secondary metabolites of lipid peroxidation was evaluated with reference to the standard solution of butylated hydroxyl toluene (BHT). The supernatant was subjected to UVvisible spectrophotometric analysis at $532 \mathrm{~nm}$ (Udayaprakash et al., 2015).

$\%$ Inhibition $=$ Absorbance of the control (Ac) - Absorbance of the sample $($ As $) \times 100$

Total Phenolic Content (TPC) Assay: FolinCiocalteu method was followed for the determination of the total phenolic content of the fungal extract. Distilled water (500 $\mu \mathrm{L})$ and FolinCiocalteu reagent $(100 \mu \mathrm{L})$ were added to 100 $\mu \mathrm{L}$ of the plant extract and incubated for $6 \mathrm{~min}$ at room temperature. The final volume was made up to $3 \mathrm{~mL}$ after addition of $1.25 \mathrm{~mL}$ of $7 \%$ sodium carbonate. The total phenolic content was expressed as milligrams of tannic acid equivalents per gram of dry weight (mg TAE/g DW) of the fungal extract, using a standard plot of Tannic acid. The absorbance was measured at $760 \mathrm{~nm}$ using UVvisible spectrophotometer (Cyber-Lab, USA) after an incubation period of $90 \mathrm{~min}$ (Barreira et al., 2008).

\section{RESULTS}

Isolation and Identification of endophytic fungi and Statistical Analysis: In this present study, in all 150 segments were screened from leaves, twigs, shoot of the selected medicinal plant. From the screened segments the isolated twelve microbes were classified into sterile morpho-species 
while eighty identified sporulating species belonged to 31 genera. Out of these Pestalotiopsis karstenii, Phyllosticta sp., Colletotrichum sp., Phomopsis sp., Xylaria sp., Alternaria alternata and Nigrospora sphaerica, were found to be dominant endophytic taxa(Figs. 1-2).

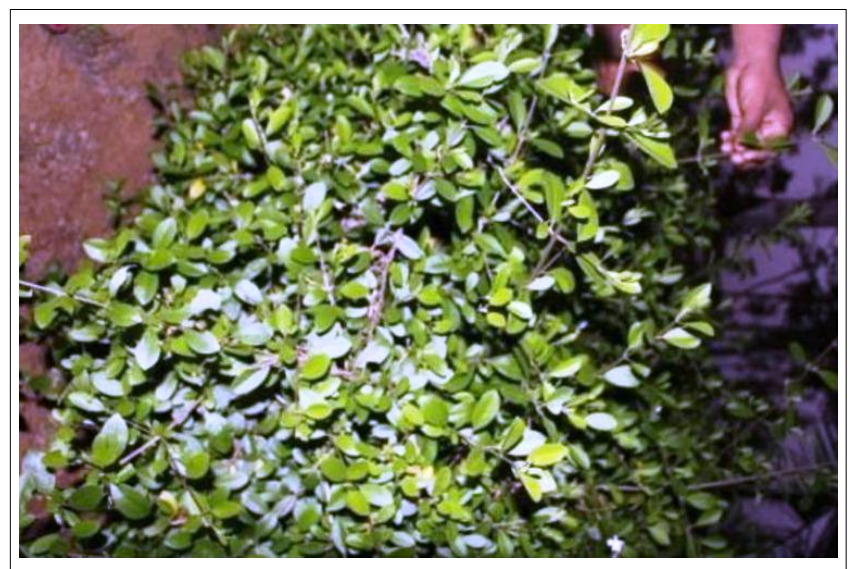

Fig. 1: Habitat of Clerodendrum inerme
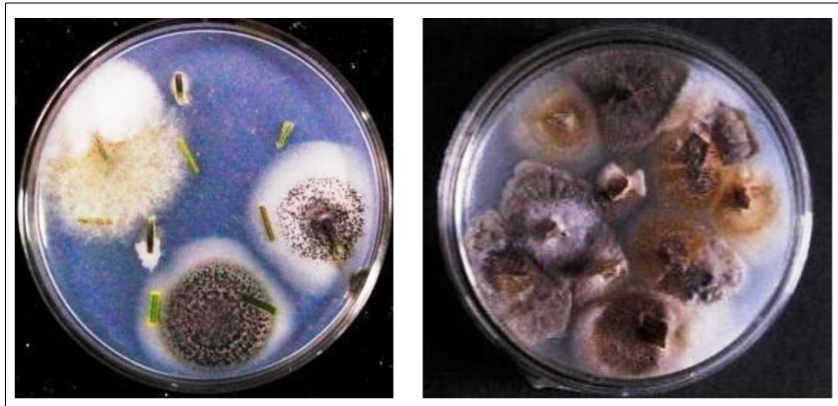

Fig. 2: Endophytic fungal propagules emerging out from tissues of Clerodendrum inerme

Colonization Frequency of different plant parts of Clerodendrum inerme: A total of 10 endophytic fungal species were recorded from the twig sample, which belonged to 8 genera and 2 sterile forms. In this sample the colonization frequency of endophytic fungal taxa was found to be dominated by coelomycetous fungi followed by hyphomycetous fungi and sterile forms. In shoot sample also a total of 10 endophytic fungal species were recorded, which belonged to 6 genera and 3 sterile forms. In this the colonization frequency of endophytic fungi was again found to be dominated by coelomycetous members followed by hyphomycetous fungi, some members of Ascomycetes and sterile forms. In case of leaves a total of 14 endophytic fungal species were recorded, which belonged to 8 genera and 6 sterile forms. Here also the colonization frequency of endophytic fungi was dominated by coelomycetous fungi followed by sterile forms, hyphomycetous fungi and some Ascomycetes (Fig: 3).

Relative Percentage Occurrence (RPO) of endophytes in different plant parts: The maximum RPO amongst the different groups of endophytic fungi from the twig sample was of coelomycetous fungi $(65 \%)$ followed by

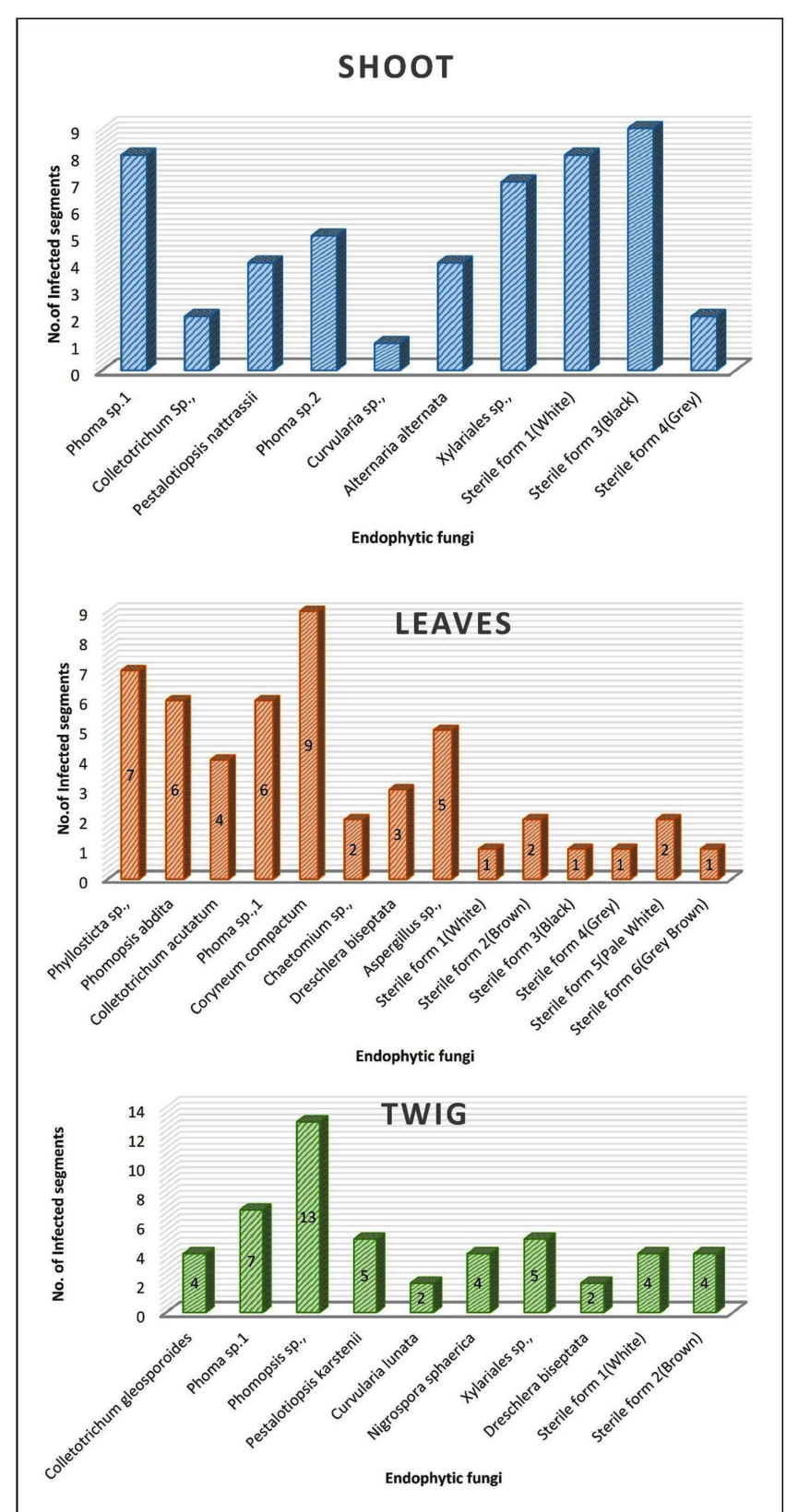

Fig. 3: Colonization Frequency of endophytes recorded from the tissues of leaves, twigs and shoots of Clerodendrum inerme.

hyphomycetous fungi (25\%) and sterile forms (22\%). Similarly in the shoot sample coelomycetous endophytic fungi $(64 \%)$ were maximum followed by hyphomycetous fungi (9\%), Ascomycetes (8\%) and sterile forms (19\%). In the leaves sample as well maximum relative percentage was of endophytic coelomycetous members (38\%) followed by hyphomycetous members (32\%), Ascomycetes (4\%) and sterile forms $(26 \%)$ (Fig. 4$)$.

Jaccard's Similarity Co-efficient: The Jaccard similarity Co-efficient of Leaves and shoot was found to be $26 \%$ followed by that of leaves and twigs (20\%) and twig and shoot (17\%). (Fig.5) 


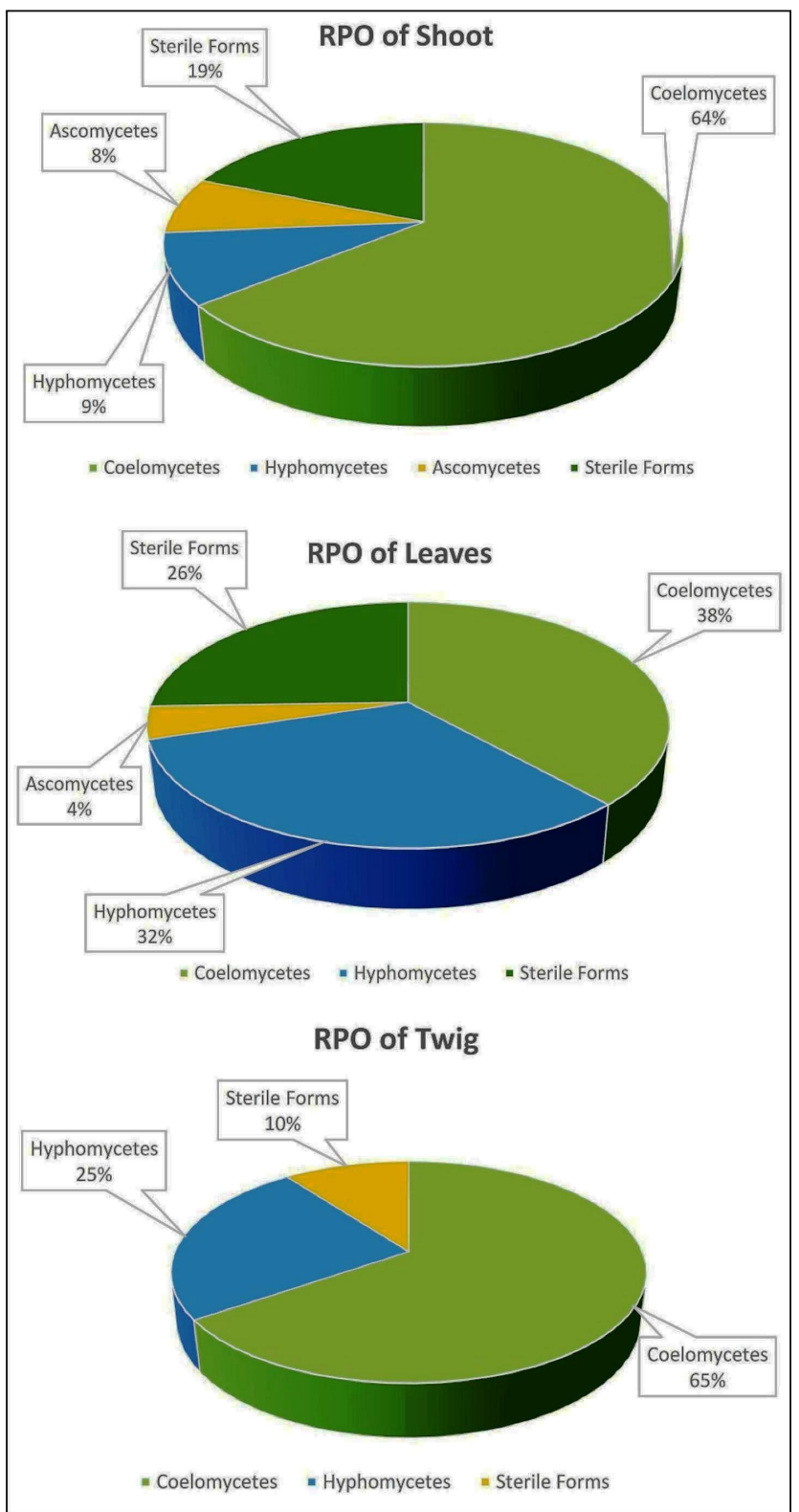

Fig. 4: Relative Percentage occurrence of endophytes recorded form tissues of leaves, twigs and shoots of Clerodendrum inerme.

Biodiversity Indices of fungal endophytes in different plant parts: The Biodiversity Indices of fungal endophytes in twig (Gleason Index :2.3125; Relative Index of Gleason: 0.1875; Shannon Diversity Index: 0.25715; Shannon Evenness:0.11168; Relative Index of Shannon: 0.06607), shoot (Gleason Index: 2.3005; Relative Index of Gleason:0.1836; Shannon Diversity Index: 0.2752; Shannon Evenness: 0.1195; Relative Index of Shannon: 0.0703) and the leaves (Gleason Index: 3.3230; Relative Index of Gleason: 0.2653; Shannon Diversity Index: 0.2752; Shannon Evenness : 0.1043; Relative Index of Shannon:0.0703) are depicted in Fig. 6 .

Agar Well Diffusion Plate Assay for antibacterial activity: The endophytic fungal extract was evaluated for its

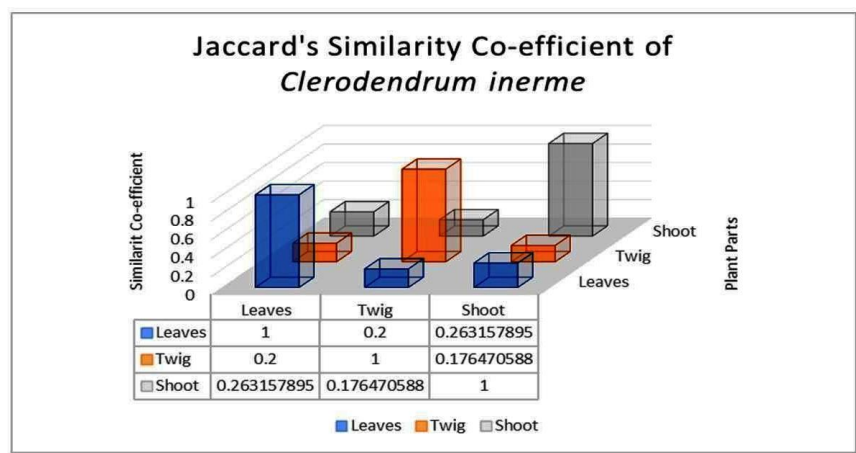

Fig. 5: Jaccard's Similarity Co-efficient of Clerodendrum inerme.
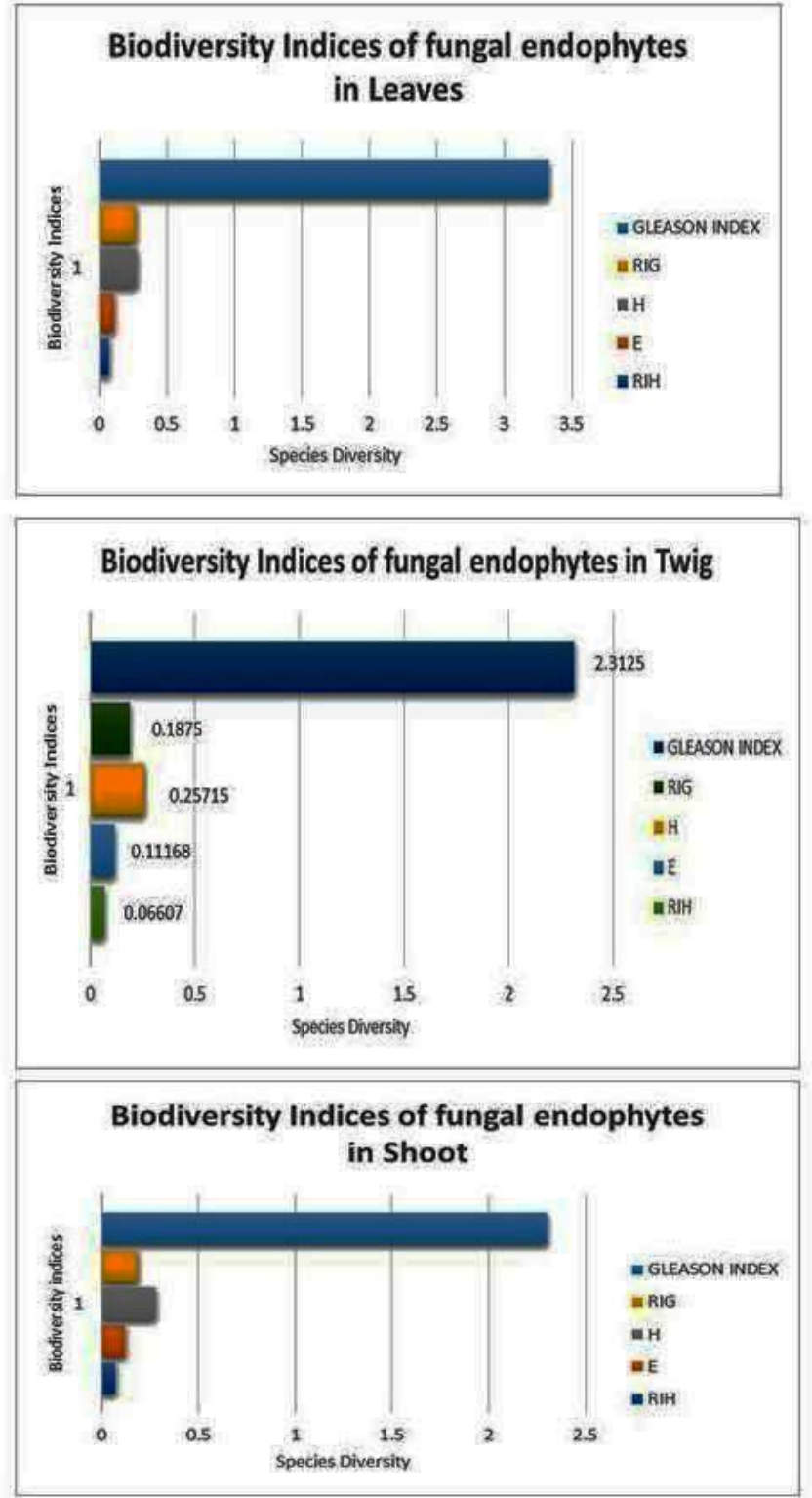

Fig. 6: Biodiversity Indices of Leaves, Twig and Shoots of Clerodendrum inerme.

antibacterial activities by agar well diffusion plate assay which exhibited the inhibition range of 15-22 mm (Table 1). The minimum inhibitory concentration showed the antibacterial potency at lower concentration $(12.5-25 \mu \mathrm{g} / \mathrm{mL})$ 
Table 1: Antibacterial activities of Colletotrichum sp. 1 compared with Positive control through Agar-well Diffusion Method

\begin{tabular}{|c|l|c|c|}
\hline $\begin{array}{c}\text { S. } \\
\text { No }\end{array}$ & \multicolumn{1}{|c|}{ Organism } & $\begin{array}{c}\text { Control Streptomycin } \\
\text { Diameter }(\mathbf{m m})\end{array}$ & $\begin{array}{c}\text { Fungal Extract Diameter } \\
(\mathbf{m m}) \text { Colletotrichum sp. 1 }\end{array}$ \\
\hline $\mathbf{1}$ & Bacillus subtilis & $20 \mu \mathrm{L}-22 \pm 3.1$ & $20 \mu \mathrm{L}-6.3 \pm 3.50$ \\
& (MTCC 121) & $40 \mu \mathrm{L}-29.21 \pm 6.34$ & $40 \mu \mathrm{L}-12 \pm 1.34$ \\
& $60 \mu \mathrm{L}-31.62 \pm 2.12$ & $60 \mu \mathrm{L}-15.4 \pm 1.45$ \\
\hline $\mathbf{2}$ & $\begin{array}{l}\text { Staphylococcus } \\
\text { aureuss }\end{array}$ & $20 \mu \mathrm{L}-18.78 \pm 1.91$ & $20 \mu \mathrm{L}-9.21 \pm 3.47$ \\
& (MTCC 3160) & $60 \mu \mathrm{L}-25.41 \pm 2.61$ & $40 \mu \mathrm{L}-12.86 \pm 1.13$ \\
\hline \multirow{3}{3}{} & Lactobacillus lactis & $20 \mu \mathrm{L}-20 \pm 2.21$ & $60 \mu \mathrm{L}-21.68 \pm 2.12$ \\
& (MTCC 4185) & $40 \mu \mathrm{L}-26.22 \pm 2.38$ & $40 \mu \mathrm{L}-15.39 \pm 2.35$ \\
& & $60 \mu \mathrm{L}-31.33+1.52$ & $60 \mu \mathrm{L}-18.31 \pm 1.18$ \\
\hline $\mathbf{4}$ & Proteus vulgaris & $20 \mu \mathrm{L}-17.37 \pm 1.8$ & $20 \mu \mathrm{L}-11.94 \pm 1.03$ \\
& (MTCC 426) & $40 \mu \mathrm{L}-22.16 \pm 1.13$ & $40 \mu \mathrm{L}-16.10 \pm 1.81$ \\
& & $60 \mu \mathrm{L}-26.33 \pm 2.12$ & $60 \mu \mathrm{L}-20.13 \pm 1.89$ \\
\hline $\mathbf{5}$ & Escherichia coli & $20 \mu \mathrm{L}-19.34 \pm 3.17$ & $20 \mu \mathrm{L}-11.27 \pm 2.14$ \\
& (MTCC 433) & $40 \mu \mathrm{L}-24.46 \pm 1.18$ & $40 \mu \mathrm{L}-14.22 \pm 2.21$ \\
& & $60 \mu \mathrm{L}-28.35 \pm 1.39$ & $60 \mu \mathrm{L}-19.27 \pm 1.01$ \\
\hline $\mathbf{6}$ & Klebsiella & $20 \mu \mathrm{L}-14.81 \pm 1.02$ & $20 \mu \mathrm{L}-7.29 \pm 1.47$ \\
& plenticola & $40 \mu \mathrm{L}-19.03 \pm 0.78$ & $40 \mu \mathrm{L}-11.12 \pm 1.38$ \\
& (MTCC 530) & $60 \mu \mathrm{L}-28 \pm 1.56$ & $60 \mu \mathrm{L}-17.23 \pm 1.39$ \\
\hline
\end{tabular}

with all gram positive and gram negative bacterial strains studied (Table 2).

Quantification of antioxidant assays: The antioxidant and free radical scavenging activities were documented around $99 \%$ inhibition at the concentration of $6.25-20 \mathrm{mg} / \mathrm{mL}$. The endophytic fungal extract was evaluated for antioxidant and free radical scavenging ability through DPPH, FRAP, FTC,

Table 2: Minimum Inhibitory Concentration of Colletotrichum sp.1., compared with positive control

\begin{tabular}{|c|c|c|c|c|c|c|}
\hline & \begin{tabular}{|c|}
$\begin{array}{c}\text { Bacillus } \\
\text { subtilis } \\
\text { (MTCC } \\
121)\end{array}$ \\
\end{tabular} & \begin{tabular}{|c}
$\begin{array}{c}\text { Staphylococcus } \\
\text { aureus } \\
\text { (MTCC 3160) }\end{array}$ \\
\end{tabular} & \begin{tabular}{|c|} 
Lactobacillus lactis \\
(MTCC 4185)
\end{tabular} & $\begin{array}{c}\text { Proteus } \\
\text { vulgaris } \\
\text { (MTCC } \\
\text { 426) }\end{array}$ & $\begin{array}{c}\text { Klebsiella } \\
\text { plenticola } \\
\text { (MTCC 530) }\end{array}$ & $\begin{array}{c}\text { Escherichia } \\
\text { coli } \\
\text { (MTCC 433) }\end{array}$ \\
\hline & $\mu \mathrm{g} / \mathrm{ml}$ & $\mu \mathrm{g} / \mathrm{ml}$ & $\mu \mathrm{g} / \mathrm{ml}$ & $\mu \mathrm{g} / \mathrm{ml}$ & $\mu \mathrm{g} / \mathrm{ml}$ & $\mu \mathrm{g} / \mathrm{ml}$ \\
\hline \begin{tabular}{|l|} 
Fungal \\
Extract
\end{tabular} & 12.5 & 6.25 & 12.5 & 25 & 6.25 & 12.5 \\
\hline Positive & 3.125 & 3.125 & 3.125 & 3.125 & 3.125 & 3.125 \\
\hline Negative & 25 & 25 & 50 & 50 & 50 & No Inhibition \\
\hline
\end{tabular}

TBA and TBA assay (Figs. 7-11). The total phenolic content of was found to be $3.142-4.445 \pm 2.85 \mu \mathrm{g} / \mathrm{mL}$ compared with Standard Tannic Acid (Fig. 11).

\section{DISCUSSIONAND CONCLUSION}

Antioxidant compounds from endophytic fungi are known to have anti-inflammatory, anti-tumor, antibacterial and antiviral activity (Owen, 2002; Sala et al., 2002; Halliwell,

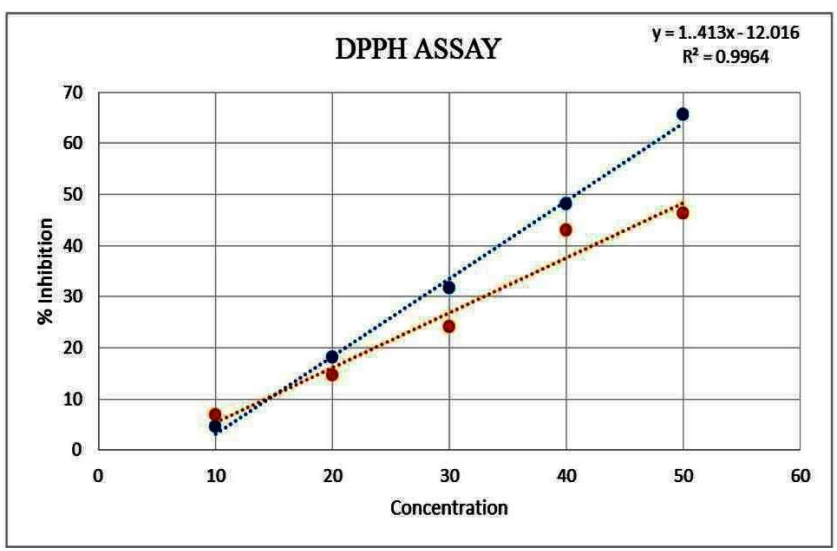

Fig. 7: Quantified DPPH assay of Colletotrichum sp.,1

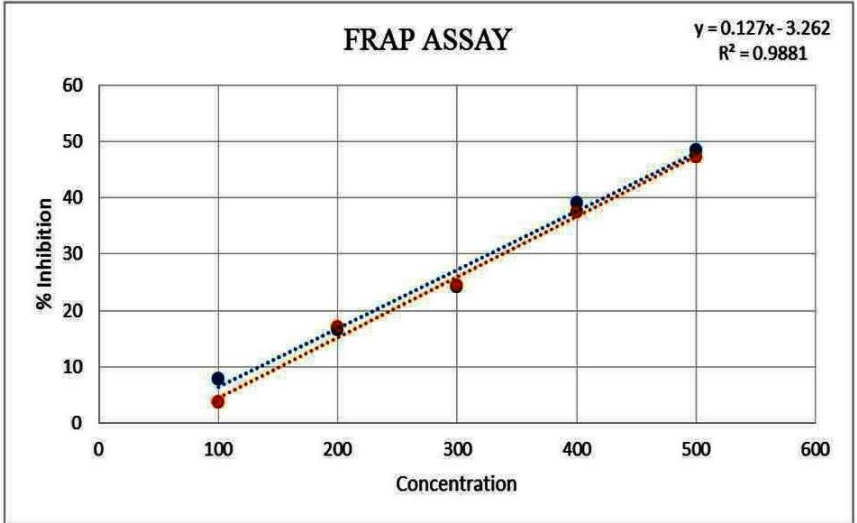

Fig. 8: FRAP quantification of Colletotrichum sp.,1

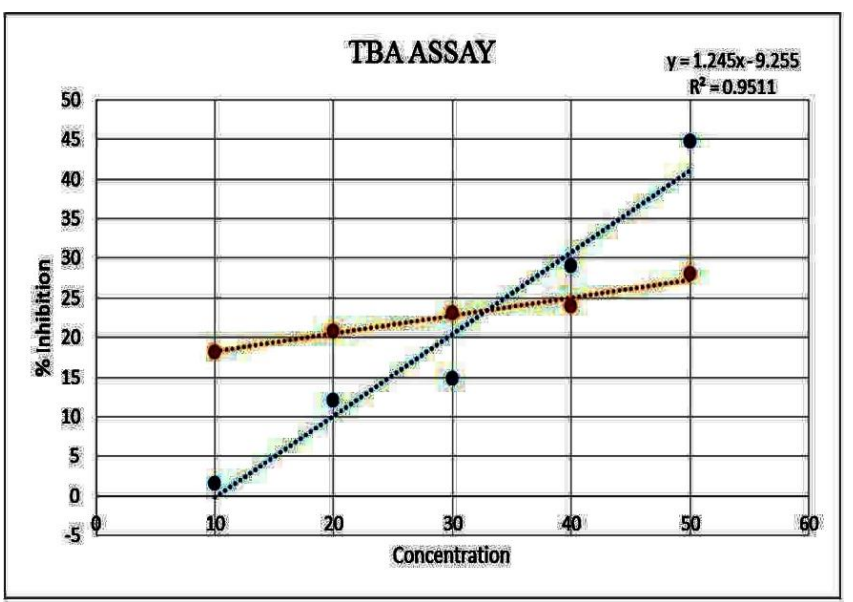

Fig. 9: TBA quantification of Colletotrichum sp.,1

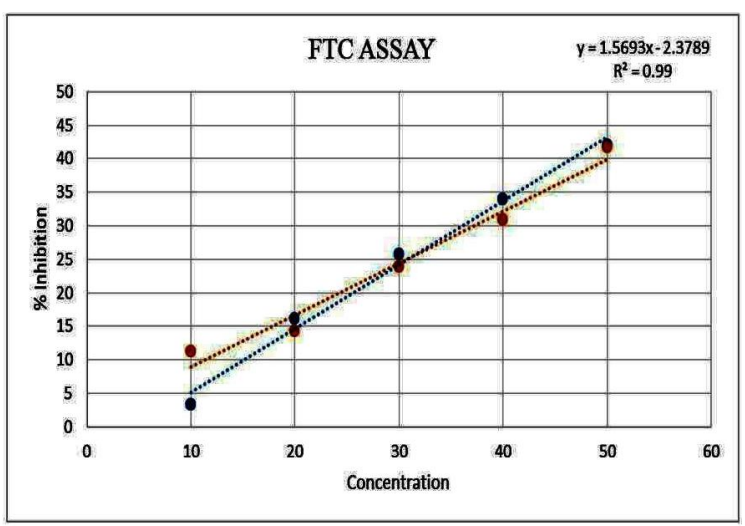

Fig. 10: Quantification ofFTC assay for Colletotrichum Sp.1

1994). Endophytic fungi known to produce antibiotic substances are reported to be play an important role in pathogenic conditions (Guo et al., 2008). In this present study, 150 segments were screened from leaves, twigs and shoots of the selected medicinal plant. Out of the total isolated endophytic fungi, twelve isolates were classified into sterile morphospecies and eighty sporulating species belonging to 31 genera. Out of these Pestalotiopsis karstenii, Phyllosticta sp., Colletotrichum sp., Phomopsis sp., Xylaria sp., Alternaria alternata, Nigrospora sphaerica. were found to be quite dominant in the host 


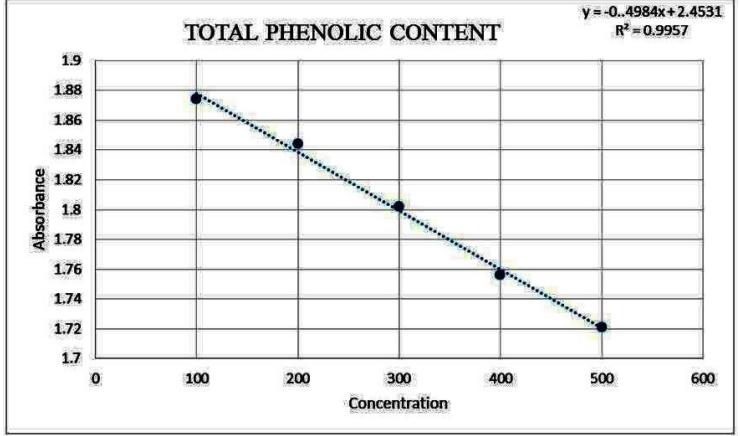

Fig. 11: Quantification of Total Phenolic Content from Colletotrichum sp.1

tissues. Dominant endophytic fungi primarily belonged to Coelomycetes followed by Hyphomycetes, Sterile forms and Zygomycetes. Relative percentage occurrence showed that Coelomycetes were dominant in shoot, sterile forms in leaves and twig. Jaccard's similarity coefficient was maximum for leaves-twigs $(0.20)$ followed by leaves-shoot $(0.2631)$ and twigs-leaves $(0.1764)$. The Gleason index $(\mathrm{G})$ and Shannon index of leaf, shoot, and twigs showed the maximum species diversity. The endophytic infection rate was found to be $100 \%$ in leaves and shoot whereas $98 \%$ infection rate was found in twig. The endophytic fungal extract when evaluated for its antibacterial activities exhibited the inhibition range of 15-22 mm. The minimum inhibitory concentration showed the antibacterial potency at lower concentration of $12.5-25 \mu \mathrm{g} / \mathrm{mL}$ with the all gram positive and gram negative bacterial strains presently studied (Table 2). The antioxidant and free radical scavenging activity recorded depicted $99 \%$ inhibition at the concentration of $6.25-20 \mathrm{mg} / \mathrm{mL}$. The total phenolic content was found to be $3.142-4.445 \pm 2.85 \mu \mathrm{g} / \mathrm{mL}$ compared with Standard Tannic Acid .The endophytic fungal extract was evaluated for antioxidant and free radical scavenging ability through DPPH, FRAP, FTC, TBA and TBA assay. There are reports of occurrence of bioactive compounds, including antifungal agents in Xylaria sp., from different hosts (Pongcharoen et al., 2008).

\section{ACKNOWLEDGEMENTS}

This work was financially supported by Directorate of Extramural Research \& Intellectual Property Rights (ER \& IPR), Defense Research Development Organization (Ref. No. IP/ER/1104597/M/01M1493 dated 14 Nov.2013.).The authors are grateful to Divisional Forest Officer and Field Director, Tamil Nadu Forest Department, Sathyamangalam and Haasanur Division for their kind help during plant sample collection (Ref.No.WL5(A)/25814/2015 dated on 09 February. 2016). We also acknowledge the help rendered by the National Biodiversity Authority, Chennai. The authors are also thankful to Botanical Survey of India, Southern Division, and Coimbatore, India for identifying the medicinal plant.

\section{REFERENCES}

Akone. S.H., Daletos, G., Lin, W., Proksch, P. and Unguisin, F. 2016. A new cyclic peptide from the endophytic fungus Mucor irregularis. Zeitschrift fur Naturforschung C, Journal of biosciences 71:15-19.

Bacon,C.W. and White, J.F. 2000. Microbial Endophytes. Marcel Dekker, New York, pp: 341-388.

Barreira, J.C.M., Ferreira, I.C.F.R., Oliveira, M.B.P.P. and Pereira, J.A., 2008. Antioxidant activities of the extracts from chestnut flower, leaf, skins and fruit. Food Chem. 107: 1106-1113.

Bicas, J.L., Dionisio, A.P. and Pastore, G.M. 2009. Biooxidation of terpenes: An approach for the flavor industry. Chem. Rev. 109: 4518-4531.

Cannon, P. F. and Simmons, C.M. 2002. Diversity and host preference of leaf endophytic fungi in the Iwokrama Forest Reserve, Guyana, Mycologia 94: 210-220.

Ellis, M.B. 1971. Dematiaceous hyphomycetes. X. Mycological Papers 125:1-30

Guba, E.F. 1961. Monograph of Monochaetia and Pestalotia $: 1-342$

Guo, B., Wang, Y., Sun, X. and Tang, K. 2008. Bio-active natural products from endophytes: A review. Applied Biochem. Microbiol. 44: 136-142.

Halliwell, B., 1994. Free radicals, antioxidants and human disease: Curiosity, cause, or consequence. Lancet 344: $721-724$.

Huang, W.Y., Cal, Y. Z. Xing, J. Corke, H. and M. sun, 2017. A potential antioxidant resource: Endophytic fungi from medicinal plants. Econ. Bot. 61: 14-30.

Kannan, K.P., Thilakavathi, R., Kumar, M.D. and Senthamarai, M. 2017. Biodiversity of Endophytic Fungi from Mukia maderespatana (L.) M. Roem - A First Report. J. Bacteriol. Mycol. (Open Access) 4 (4): 1-7

Krings, U., Hardebusch, B., Albert, D., Berger, R. G., Marostica Jr, M. and Pastore, G. M. 2006. Odoractive alcohols from the fungal transformation of afarnesene. J. Agric. Food Chem. 54:9079-9084.

Kumar, S. and Sagar, A. 2007. Microbial associates of Hippophae rhamnoides (Seabuck thorn) Plant Pathol. J. 6:299-305.

Liu, X., Dong, M. Chen, X., Jiang, M., Lv, X. and Yan,G. 2007. Antioxidant activity and phenolics of an endophytic Xylaria sp. from Ginkgo biloba. Food Chem. 105: 548-554.

Liu, Y., Li, Y., Qu, J., Ma, S-G., Zang, C. and Zhang, Y. 2015. Eremophilane Sesquiterpenes and Polyketones Produced by an Endophytic Guignardia Fungus from the Toxic Plant Gelsemium elegans. J. Nat. Prod. 78:2149-2154.

Liu, J., Luo, J., Ye, H., Sun, Y. Lu, Z. and Zeng, X. 2009. Production, characterization and antioxidant activities in vitro of exopolysaccharides from endophytic bacteriuun Paenibacillus polymyxa 
EJS-3. Carbohydrate Polymers 78: 275-281.

Liu, X., Dong, M., Chen, X., Jiang, M. Lv, X. and Zhou, J. 2008. Antimicrobial activity of an endophytic Xylaria sp sp.X-28 and identification of its antimicrobial compound 7-amino-4methylcoumarin. Applied Microbiol. Biotechnol. 78: 241-247.

Mahapatra, S. and Banerjee, D. 2010. Diversity and screening for antimicrobial activity of endophytic fungi from Alstonia scholaris. Acta Microbiol. Immunol. Hung. 57:215-223.

Mallette, N., Pankratz, E.M., Parker, A.E., Strobel, G.A., Busse, S.C., Carlson, R.P., et al. 2014. Evaluation of Cellulose as a Substrate for Hydrocarbon Fuel Production by Ascocoryne sarcoides (NRRL 50072). Journal of Sustainable Bioenergy Systems 4: 33-49.

Mussagy, C.U., Winterburn, J., Santos-Ebinuma, V.C. and Pereira, J.F.B. 2019. Production and extraction of carotenoids produced by microorganisms. Appl. Microbiol. Biotechnol. 103 (3): 1095-1114.

Nag Raj, T.R. 1993. Coelomycetous anamorphs with appendage-bearing conidia. :1-1101

Owen, R.W., Giacosa, W.E, Hull, R., Haubner, B.S. and Bartsch, H. 2000. The antioxidant/anticancer potential of phenolic compounds Isolated from olive oil. Eur. J. Cancer 36: 1235-1247.

Petrini, O. 1986. Taxonomy of endophytic fungi of aerial plant tissues. In: Microbiology of the phyllopshere (Eds.: Fokkema, N. J. and 1Van.DenHeuvel). Cambridge University Press, Cambridge, UK:175187.

Pongcharoen, W. , Rukachaisirikul, V., Phongpaichit, S., Kuhn,T. , Pelzing, M., Sakayaroj , J. and Taylor, W.C. 2008. Metabolites from the endophytic fungus Xylaria sp., PSU-D14. Phytochemistry 69: 19001902.

Sala, A. , Del Carmen Recio, M., Giner, R. M., Manez, S. and Tourmer, H. et al., 2002. Anti-inflammatory and antioxidant properties of Helichry sumitalicum. $J$. Phamn. Phamnacol. 54:365-371.

Strobel,G. and Daisy, B. 2009. Bioprospecting for microbial endophytes and their natural products. Microbiol. Mol. Biol.Rev. 67: 491-502.
Sutton, B.C. 1980. The Coelomycetes. Fungi imperfecti with pycnidia, acervuli and stromata. :1-696

Suryanarayanan T.S., Murali, T. S., and Venkatesan, G. 2002. Occurrence and distribution of fungal endophytes in tropical forests across a rainfall gradient. Can.J.Bot. 80: 818-826.

Tamilarasan, K., Nanthini, R., Prakash, N. Rajkumar, E., Renganathan, N. G. and Udayaprakash, N. K. 2013. Evalution of antimicrobial property of few types of co-polyester, International Journal of Research in Pharmaceutical Sciences 4: 604-607.

Tan, R.X. and Zou, W. X. 2001. Endophytes: a rich source of functional metabolites, Nat.Prod.Rep. 18: 448-459.

Udayaprakash, N.K, Bhuvaneswari, S., Balamurugan, A., Vaishnavi, S., Sunisha Sugunan, Sindhu Meena, Chandran, M. and Sekar Babu, H. 2013. 'Studies on antibacterial, antioxidant, larvicidal, pesticidal activities and phytochemistry of Leonotisne petifolia (Linn) R.Br. International Journal of Research in Pharmaceutical Sciences 4: 2, 303-309.

Udayaprakash N.K., Ranjith Kumar, M., Deepa, S., Sripriya, N., Abdulla, A. Al-Arfaj and Bhuvaneswari, S. 2015. Antioxidant, free radical scavenging and GCMS composition of Cinnamom uminers Reinw. ex Blume. Industrial Crops and Products 69: 175179.

Wani, M.C, Taylor, H. L., Wall, M. E., Coggon, P. and McPhail, A. T. 1971. Plant anti-tumor agents VI. The isolation and structure of Taxol, a novel anti leukemic and anti tumour agent from Taxus brevifolia. J.Am. Chem.Soc. 93: 2325-2327.

Yang, X-1, Huang, L., Li, H-Y., Yang, D-F. and Li, Z-Z. 2015. Two new compounds from the plant endophytic fungus Pestalotiopsis versicolor. J. Asian. Nat. Prod. Res. 17 (4):333-337.

Yu, H., Zhang, L., Li, L., Sun, P. and Qin, L. et al. 2010. Recent developments and future prospects of antimicrobial metabolites produced by endophytes. Microbiological Res. 165: 43 7-449

Zhang, Y., Park, K. Y., Suazo, K. F. and Distefano, M. D. 2018. Recent progress in enzymatic protein labelling techniques and their applications. Chem. Soc. Rev. 47: 9106-9136. 